the berry supply around the Forestry Farm was getting low. Perhaps this forced waxwings to search for alternte food. Or did this flock just luck out and find a preferred protein-rich food supply at a convenient time?
'BENT, A.C. 1950. Life Histories of North American wagtails, shrikes, vireos and their allies. Smithsonian institute, U.S. National Museum Bull. 197.

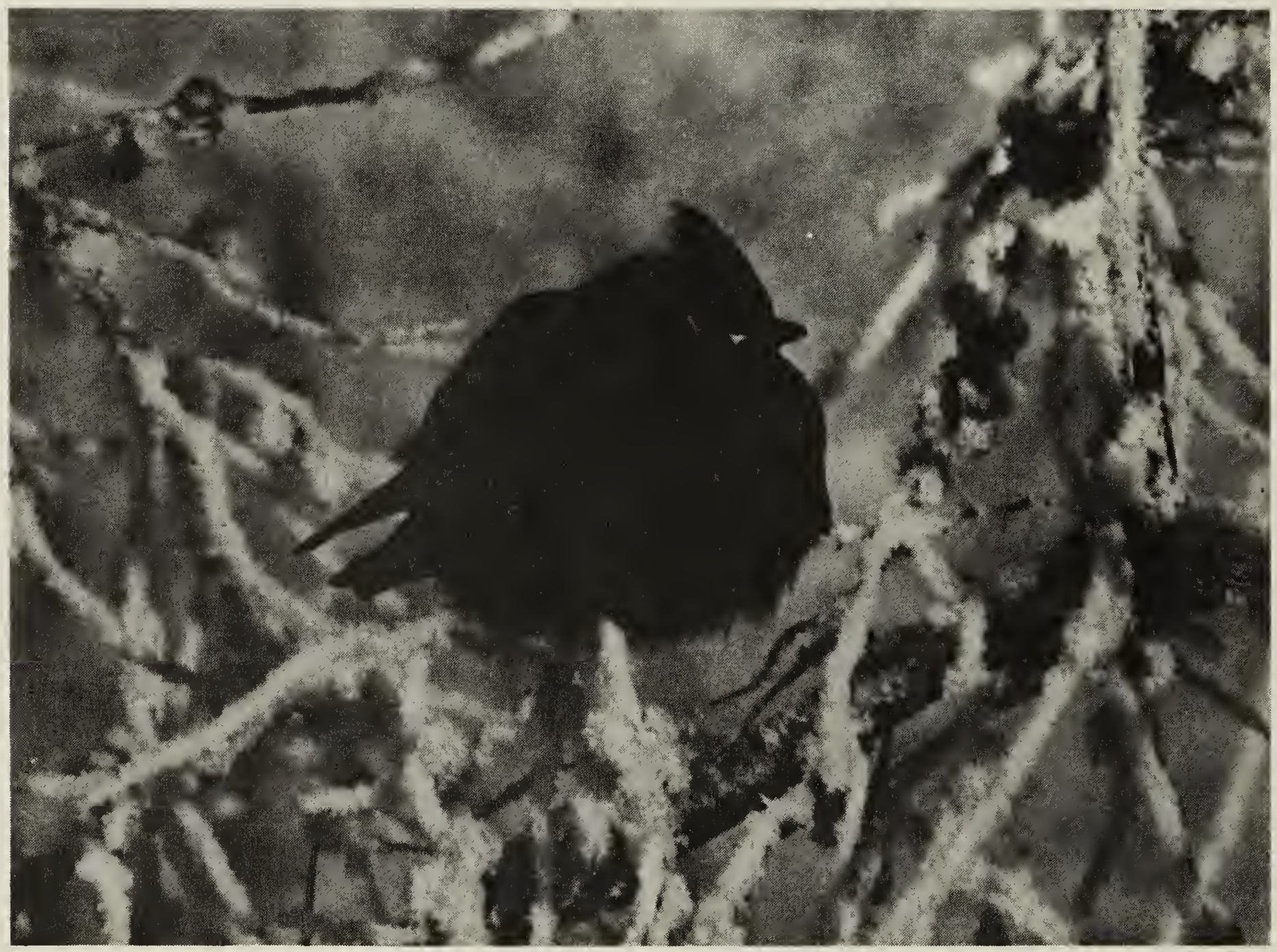

Bohemian Waxwing

Juhachi Asai

\title{
RUFOUS HUMMINGBIRD SIGHTING
}

JEAN HILTON and GEORGE HILTON, R.R. \# 1, Bangor, Saskatchewan. SOA OEO

In Saskatchewan parkland, about 25 miles north of Round Lake (Qu'Ap. pelle Valley), we usually have a pair of Ruby-throated Hummingbirds around the yard each year and we thoroughly enjoy watching them as they dart from flower to flower sipping nectar.

Christmas 1983 delivered a hummingbird feeder which we hung about 3 feet in front of the kitchen 
sink window. By early July the number frequenting the feeder had grown to five and the male had disappeared. This made identification of the iridescent green-backed individuals difficult. With windows open, we enjoyed their shrill squeaks as they chased each other, which they did as often as they hovered to sip syrup.

Then came a big surprise. On 31 July a newcomer was trying to feed and the Ruby-throateds were challenging his presence. The newcomer was obviously a hum. mingbird, but he had a cinnamonbrown back and an orange-red throat. We dashed for Field Guide To Western Birds (Peterson, 1961) and found that a Rufous Hummingbird was our guest. We named him "Rufous". Rufous was pugnacious and within 24 hours he had established himself as boss hummingbird. He would sit on a bare spruce branch about 8 feet from the feeder and chase off the Ruby-throateds who tried to feed. In fact, the only way they could feed at times was to come in twos and threes and one could feed while Rufous was combatting the others.

Rufous would sit on the spruce branch, guarding the feeder, and at times his throat would look a dark brown color. Then, without any apparent movement, his throat would flash the brilliant orange, a beautiful sight.

Many happy minutes were spent watching the Ruby-throateds and Rufous, and we were surprised to note that Rufous had a different feeding position. The body of the Ruby-throated angles up to the bill which is held parallel to the ground when feeding. The Rufous however, holds its body parallel to the ground and its bill angles downward to the feeder.

Rufous stayed with us exactly one week, departing on 7 August. It would be interesting to know why he wandered so far east and if he returned safely to his own species in the western mountains.

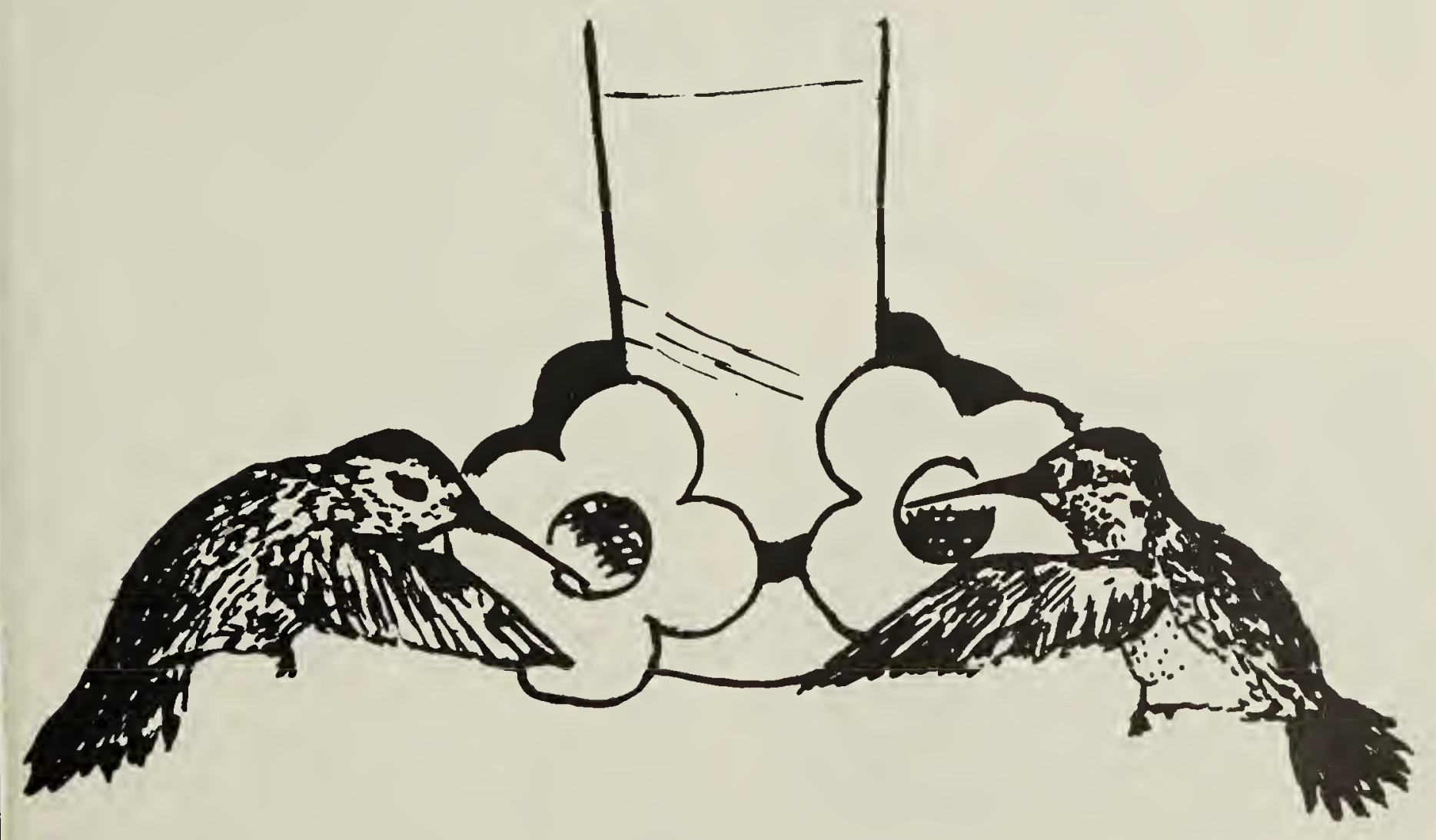

Rufous

Ruby-throated 